DOI: https://doi.org/10.47405/mjssh.v6i5.773

\begin{tabular}{|c|c|}
\hline$\sqrt{15}$ & Malaysian Journal of Social Sciences and Humanities (MJSSH) \\
\hline Malaysian Journal of & Volume 6, Issue 5, May 2021 \\
\hline (MJ-sSH) & e-ISSN : 2504-8562 \\
\hline & $\begin{array}{c}\text { Journal home page: } \\
\text { www.msocialsciences.com }\end{array}$ \\
\hline
\end{tabular}

\title{
Improve Malay Vocabulary Among Year 5 National Type School Pupils Through Gape Activity
}

\author{
Nithiya Raju Retnam ${ }^{1}$, Fariza Binti Khalid ${ }^{1}$ \\ 1Education Faculty, The National University of Malaysia
}

Correspondence: Nithiya Raju Retnam (p99159@siswa.ukm.edu.my)

\begin{abstract}
Malay language acquisition among National Type School (NTS) is not at a satisfactory level. Malay language is important for Malaysians because it is the main communication language all over Malaysia. The Ministry of Education also makes it compulsory to all Malaysian students to pass the Malay language in examinations. The researcher's preliminary review shows that NTS pupils have difficulties in identifying verbs which is equivalent to Sivaneswary's research (2019) which shows NTS pupils are weak in identifying verbs in Malay language. They also face difficulties communicating in Malay because lack in vocabulary of verbs. The previous studies show that NTS pupils need to improve in Malay language. Studies also show that lack in vocabulary can affect pupils' ability in communicating in Malay. However, there is not much research done to NTS pupils in improving their vocabulary of verbs. Therefore, an action research which includes quantitative and qualitative approach has been done to 30 year 5 NTS pupils. A language activity was carried out to pupils to improve their vocabulary in verbs. Data from pre and post-examinations, and interviews were analysed to examine the effectiveness of the activity introduced. Data shows that the activity has improved pupils' ability in finding correct verbs. Furthermore, they are found to be motivated to take part in Malay lessons and communications. This research can be done in NTS schools for Malay lessons to aid pupils to improve their Malay vocabulary in verbs and drive them to communicate this language. Teachers can create a lively and entertaining lesson too.
\end{abstract}

Keywords: Malay language, vocabulary, verbs, National Type School, communication

\section{Introduction}

Language is a country's identity. Malaysia is a multiracial country with many languages spoken in daily life of the citizens. Among all the languages, Malay language is considered as the most spoken language in Malaysia (Maznida, 2018). It is also this country's national language. Maznida (2018) also said that there are some features that make Malay a civilized language such as a high number of native speakers and this language is used by traders as well as colonizers for communication. Malay language is also believed to be a powerful tool to unite Malaysians (Mohd. Khaidir, 2019). Malay language is one of the must pass subjects in the examination of Malaysia. It consisted of listening and speaking, reading and writing. A student must be good in Malay vocabulary to go through all the skills.

Although Malay is widely spoken, it is still difficult to be adapted by pupils from National Type School (NTS) which stands with non-Malay pupils such as Indians and Chinese. This was highlighted by Chew Fong Peng (2016), Rahman (2018) and Sivaratnam (2019) in their research that NTS pupils' performance 
in Malay language is still at the unsatisfactory level. NTS in Malaysia has two types. They are Tamil and Chinese. NTS uses their mother tongue as a medium for teaching and learning. These schools mostly consist of people of their own race. This shows that all the pupils are exposed to their own mother tongue.

It is very important for them to master Malay language, the prime language of Malaysia which is being the second language to them. Second language is a language learned after mastering a big part of sounds, structures and vocabularies of one's mother tongue (Mariyati et al., 2017). Siti et al. (2020) also has said that mastering Malay language is being a problem for students whose second language is Malay. These pupils are less exposed to Malay language because the main language used in NTS is Tamil and Chinese language. This results in the pupils communicating more using their mother tongue in school. This is supported by Nora'azian and Fadzilah (2018) research which proves that the usage of Malay language in communication among NTS pupils are very low. On the other hand, pupils from NTS school must pass the Malay examination in primary school so that they don't have to enter Transition classes in secondary for one year before entering Form 1. Apart from that, most of the subjects in NTS are taught using their mother tongue which is Tamil and Chinese.

The pupils also prefer to talk in their mother tongue with their peers who are all from the same race. In addition, the non-Malay pupils have been exposed to their mother tongue since young (Zamri et. al., 2016). Chew (2016) mentioned in his research that there is a wrong concept among NTS pupils who thinks that Malay language is not important to them and it is used for casual purposes.

Not only that, the way of teaching Malay also affects this situation. Based on observations made by researcher, teachers are still using the conventional or 'chalk and talk' method in Malay teaching and learning activities especially for level two pupils in NTS. Pupils often feel bored and less motivated to learn in this way. This will also won't enhance pupils' ability to remember the learning in the class. This situation also happens because of a lack of dictionary usage among pupils in Malay language teaching and learning due to time consuming and burdensome. Knowing the meaning of verbs is also usually neglected. All these lead to lack of verb acquisition in pupils which will then affect pupil's writing and communicating skills.

They often make mistakes in using correct verbs to make sentences in Malay, Paper 2, Section A. Pupils are also found to be less communicating in Malay because of the same problem. Moreover, the issue of selecting appropriate words in daily conversation among non-native speakers of Malay language in Malaysia has exposed them to the risk of misunderstanding and will likely loosen social cohesion (Noor Azam \& Noraziah, 2018).

Therefore, a research has been carried out to improve these pupils Malay language acquisition. It focuses on Malay vocabulary specifically in verbs. It is because verbs are mainly used in Malay language speaking and writing. Furthermore, previous studies show that many research has been done to improve Malay language proficiency but very few of it focuses vocabulary of Malay. In depth, very few studies have been done lately which concentrate Malay verbs.

The main goal of this study was to develop NTS pupils' vocabulary of verbs to help them get good marks in Bahasa Melayu Paper 2, Section A question. Other than that, pupils also need to be motivated to involve in BM lessons actively and to communicate using Malay language. This research was done to answer the questions below;

i. How far pupils' Malay language vocabulary of verbs has been improved through GAPE activity?

ii. How far pupils are feeling motivated to learn Malay language through GAPE activity?

iii. How far pupils are feeling confident to communicate in Malay language after the GAPE activity?

\section{Literature Review}

\section{Vocabulary}


Vocabulary is a crucial part of a language which is being used in our daily life (Anis et al., 2019). Dian et al. (2019), Muhammad Dalimunte et al. (2018) and Hasbullah et al. (2018) has defined and cited vocabulary as a basic element in a language which will help in developing ones ability in the language. On the other hand, Muhammad Afif (2017), Novia et al. (2018) and Iman et al. (2019) are defining vocabulary as a number of words one knows in a language to use it with other skills effectively. Equivalent to that, some researchers argue that vocabulary are words which have meanings that an individual needs to know as a part of language (Muhammad Dalimunte et al., 2018; Haya, 2019; Sarala Thulasi et al., 2019).

In contrast, Pangkuh (2020) and Yee (2016) stated that vocabulary as an important element which links in development of other language skills such as listening, speaking, reading and writing. Noviyanti et al. (2019) said that vocabulary is a source which provides knowledge that controls everything in a language. So we can conclude that vocabulary is a number of words with meanings which act as an important base of a language. It also has a connection with development of other skills in a language.

\section{Malay vocabulary acquisition}

Improving Malay vocabulary is important for the students to master the language. It is because, Noviyanti et al. (2019), Dian et al. (2019) and Novia et al. (2018) stated that vocabulary really helps in improving proficiency and competency in a language. They also said that it is most important in learning a language. It has been proved by researchers that mastering vocabulary of a language can help an individual to read and understand what they are reading (Yee, 2016; Sarala et al, 2019; Pan, 2017; Agus, 2019).

Good vocabulary among students will lead to a successful two way communication in Malay. This statement is equal to Dwi (2018), Eunice (2019) and Yuyun Bahtiar (2017). On the other hand, Malay language consists of skills such as listening, speaking, reading and writing. It is trusted that a student's ability in all the above skills can be developed through improving in vocabulary (Hasbullah et al., 2018; Novia et al., 2018; Pangkuh, 2020). In brief, if students master the vocabularies of Malay language, they can also improve their reading, communicating and writing skills in the language at the same time.

\section{Verb}

Verb is a word that describes the action done by subject. It is a part of speech (Abdul Koder et al., 2018). In all languages, the verb is the central and the most important. It is also known as a widely described phrase because the structure of it and the meanings expressed in many languages concentrate on the verb word (Dumdebabari, 2020). Moreover, the verb is accepted as the most progressive category of language (Flyuza et al., 2018). According to Yenita (2018), the verb is the multiplex part of speech.

\section{What is GaPe activity?}

The integration of technologies believed to bring new opportunities for pupils to master a language. Therefore, GAPE activity was carried out in Malay teaching and learning. GaPe is a new activity created by researcher to develop Malay vocabulary among NTS school students.

GaPe is a short form for 'Ganti Perkataan' which means replacing words in Malay. In GaPe, students will be given lyrics of Malay children songs. They then need to replace verbs that are found in the song with other words which have similar meaning. In this case, pupils will be using an online dictionary named DBP online to find the synonym of words. Not only that, pupils must also choose the correct synonym of a word to be replaced in the song because, a wrong word can ruin the meaning of a sentence (Dulay et al., 1982). After that, students are required to sing the song again with new words.

Replacing words with another will definitely increase the amount of vocabulary among students. This is equal to Widi (2016)'s, point which says finding the meaning of a word as one of strategies used to learn vocabulary in Arab language. She also stressed teachers to avoid translating or giving full definitions of 
words to students. This is to encourage students to find the meaning themselves so they won't forget easily. Rollanda et al. (2017) have cited Cromley and Azevedo's point that when students obtain a word's meaning linked from other words and related experiences, improvement in understanding happens. To sum up, usage of GaPe is believed to enhance vocabulary mastering among NTS students because it also has the same functions as in the reviewed studies.

\section{Motivation to learn}

Achieving planned learning objectives are educators main aim in teaching. To achieve the learning objectives, pupils must engage fully in the teaching and learning activities. The activities must be a stimulator to the pupils to motivate them to learn. Motivation is the main condition in learning which influences the learning process and its outcome (Mekka, 2019; Rahardjanto et al., 2019). Equal to that, Ninda (2017) and Fitri et al. (2016) said that less motivation in pupils will make them bored to learn. They will then won't achieve the learning. So, there must be a stimulator to motivate them to learn.

Motivation can improve the eagerness to learn. Hence, low motivation in learning will result in low achievement of pupils (K Fahuzan \& R H Santosa, 2018; Setiani, Sanjaya \& Jatmiko, 2019). Similar to that, Syaiful et al. (2018) said that high motivation to learn will inspire pupils' success in learning with high learning results. He also mentioned that newness and open communication can enhance pupils' motivation to learn. All the above strongly indicate that motivation is highly needed to absorb the learning content by pupils. Low motivation will build up a boring teaching and learning environment. Thus, pupils will not engage in the activities and achieve low understandings. Dwi Widayanti (2018) referred in her writings that motivation includes three main elements. First, change of energy. Second, emerge from a feeling which influences an individual's behavior. Third, motivation comes from within which is also a reaction of an action.

\section{Oral communication}

Oral communication is a key to master a language because it creates a real communicative experience in which pupils learn to express their own opinions (Jabbarova, 2020). Communicating using a language includes using lexical grammar and pronunciation events in the language (Usmonov, 2020). Jabbarova Anora (2020) in another study stated that communicating using a second language is very important because pupils who are able to communicate in a second language efficiently and clearly will succeed in school and later in every phase of life.

Lai-Mei (2017) said that many language learners don't talk using a language because they find difficulties in finding suitable words. According to her, one communicates to pass on information. Additionally, they must be both listeners and speakers for effective communication. Also mentioned in her study that communicating using specific language is very important in second language learning. Noor Azam and Noraziah (2017) explained that pupils who are able to communicate using a language appropriately with correct chosen words are considered as a proficient communicator.

In brief, communicating using a language is important to express feelings and opinion to others. Frequent communication using a second language will drill the communicator to improve in the language.

\section{Self - Confidence in speaking}

Self-confidence is an attitude or belief in self-ability which is also a main point in language learning (Wati, 2020). She also mentioned that confidence is key to assist pupils to speak and communicate their view and opinion effectively.

Furthermore, research done by Laisiyah (2017), Indawan (2017) and Tridinanti (2018) shows that selfconfidence is enhancing speaking ability which contributes to good communication. Pupils who possess elements such as bravery and believe in their abilities are considered to have self-motivation to learn language better (Bandar Mohammad \& Abdul Shakour, 2018). 
Win Listyaningrum (2017) has referred to James and Amy (2011)'s element of self-confidence in his study. According to them, being willing to take risks and going the extra mile to achieve better things are characteristics of a self-confident individu.

Carol and Kathryn (2017) defines confident communication as sharing and finding things in common in a way which creates connection and trust. She also added that someone who uses learned skill when communicating is a confident communicator. Generally, it can be concluded that self-confidence is essential in communicating effectively using a language. Speaking a language confidently also helps in language acquisition.

\section{Singing as creative approach in learning}

Creative approach is a learning concept that intends a platform and chance for the students to involve actively in teaching and learning activity. The main focus of this approach is to make the learning environment lively to avoid tedious among students (Siti Rohani et al., 2020). This approach is equivalent with 21st century teaching and learning style desired by our Ministry of Education based on communication, collaboration, critical thinking and personal value activities (4K1N - Komunikasi, Kolaborasi, Kreatif, Nilai sahsiah) (Sinar Harian, 2018).

Chuanhua (2017) has highlighted that creative teaching is expanding widely and is being a trend of education in various countries around the world. A creative teaching implies creative conditions when teaching a subject. It will obviously make students involve themself imaginatively. This statement is supported by Teresa Cremin et al. (2018). They also added that this situation will help in expanding students' generative, evaluative and collaborative range. Creativity in students comes to light when they are actively involved in exploring ideas, commence their own learning, making selections and controlling themselves on how to express themselves (Pamela \& Regina, 2017).

In the opinion of Ewa and Robert (2019), characteristics of songs such as easily accessible, effortlessly memorisable, monotonous essence, related to daily life events and attract concentration make it appropriate to be used in teaching a second language.

According to Ulrike (2017), pupils are exposed to the target language when singing. It also generates a positive feeling among students which will help in setting up a positive learning atmosphere in class. As cited by Sarah et al. (2020), students who learn language with multiple utilized intelligents like musical performance, drawing and acting, have higher mastery of vocabulary. Moreover, Alisaari and Heikkola (2017) found that integrating music by singing is very functional in the language subjects.

Dania Murad et al. (2018) said that singing activity in learning language has advantage in mastering language specifically in vocabulary acquisition. They also proved in their research that integrating singing activity results in positive outcomes in language learning. Wenying and Guofang (2017) mentioned that many pedagogical advantages are obtained from the use of songs in language teaching. They also added that students will repeat the words persistently which will develop their capability to use the word naturally when speaking the language. This fact is similar to Ewa Tomczak and Robert Liew (2019).

\section{Usage of online dictionary in improving vocabulary}

Dictionary is a tool that is recognised as momentous in learning a language as cited by Robert (2016) in his artikel. As cited by Asli (2020), a dictionary is a compilation of words in alphabetical order from a language which has general use as explaining meaning and pronunciation. He also added that a dictionary is a reference book of words of all times from a language which explicate their spelling, pronunciation, meanings, types, connotations, samples and its root. Kevin (2020) defines a dictionary as a helpful source for clarification. Dictionaries can be said to act as a 'Bible' for a language. 
Conferring dictionaries when reading can aid in prompting vocabulary (Mohamed A. Mekheimer. 2018). Debbita et al. (2017) highlighted in her studies that pairing dictionaries in reading can result in creating students who learn outside the classroom and shapes life long, independent language learners. Meanwhile, Jee a nd Hyeok (2016) found in their research that the vocabulary scores of students who use dictionaries in different types of vocabulary learning is higher than groups of students who learn without a dictionary.

As technology is developing very fast, the usage of printed dictionaries is decreasing. This is because dictionaries now can be accessed digitally online through smart phones and computers. Anna (2017) said that online dictionaries are an electronic form of digital dictionary which are becoming popular and more appropriate for students in learning language. Agnieszka et al. (2017) said that an online dictionary is a referral material that is stored in an electronic form that explains words.

An online dictionary said to be providing fast and favourable reference compared with paper-based type (Wichuda et al. 2020). This makes the online dictionary preferred and commonly used by many people (Galih, 2019). Findings by Ratmini and Dahlia in their research shows that students prefer using online dictionaries because they are handy, it motivates them to learn language, has easy and fast access, induces their language learning ability and improves their vocabulary.

In this study, pupils an online dictionary named DBP online will be used by pupils to find meaning of word and do replacement. This online dictionary was developed by Dewan Bahasa dan Pustaka (DBP). DBP is an agency under the Malaysian Ministry of Education which has autonomy to maintain and develop Malay language. DBP online is an official online dictionary. This was chosen to be used in improving Malay vocabulary because it has the latest updates of words and meanings according to the Malaysian Ministry of Education.

\section{Methodology}

The researcher used action research to solve the problem identified at the beginning of study. Students are found to be lacking in Malay vocabulary causing them to get lower marks in Malay and having problems in communicating in Malay language. So, an activity named GaPe was planned and used by researcher to overcome the problem.

Action research stands with different approaches. It functions as one of the components for supervision in education (Abdul Rahman, 2015). An action research needs to be carried out systematically to get findings which are valid and capable for reference in future. Ilaria (2011) cited in her study that as the creator of action research, Kurt Lewin used the name 'Action Research' for the first time in 1946 to introduce and expand a cooperated action for sorting out a problem in psychology through his research. In Hilary, et al. (2019)'s opinion, action research is a change in social education with different ways other than shaping the word in the desired way.

This study was carried out at a National Type School in Johor Bahru. This school is situated in a town area. This school consists of year $1-6$ students who are in the same race. The participants of this research are students from Year 5. They consist of 12 boys and 18 girls from the same age. All the students are from the same class too. This is because research will be done throughout Malay lessons in school.

Researcher is focusing on improving pupils' vocabulary mainly verbs in BM through GAPE activity. The use of correct verbs to make sentences in Bahasa Melayu, Paper 2, Section A is very important. Thus, researcher gave this activity to pupils before and after the implementation of GAPE activity. Both pre and post marks compared at the end of research to find differences in pupils marks whether improved or deteriorated.

Besides quantitative data, this research is also supported with qualitative data which collected through interviewing the pupils to strengthen the findings. An interview was carried out to 30 year 5 pupils who 
DOI: https://doi.org/10.47405/mjssh.v6i5.773

were involved in this research after implementing the GAPE activity. This is to know pupils' opinion and feelings on GAPE activity. This will also help in testing the objective of research. A set of eight questions which are suitable for their age and maturity were asked to the pupils. This was done for the validity of the data. All the answers of the pupils to the interview questions were recorded, transcribed and analyzed. The NVivo 12 software was used to do the analysis for a thorough and valid result.

The validity and reliability of the materials used has been checked with experts. Researcher consulted The Excellent Teacher for Malay subject (Guru Cemerlang Bahasa Melayu) and Malay language Panel Head in school to discuss teaching lessons to carry out GaPe activity. This activity also was validated by The Excellent Teacher for Malay subject after getting a thorough explanation about it. Kurt Lewin model of action research was followed to carry out this study;

\section{Plan}

Pupils were given the 1st set of BM, Paper 2, Section A question which consist of a picture. They need to make five sentences based on the picture using correct verbs. Their marks were collected. Researcher also prepared the teaching materials to carry out the planned activities.

\section{Act}

Researcher carried out GAPE activity. Firstly, pupils were given a few Malay children songs. Next, pupils used DBP online to find the meaning of underlined verbs in the song. Then, pupils replace the verb with another suitable synonym word. They later make sentences for the verbs. Finally, pupils sing again the song using the new lyrics.

\section{Observe}

Pupils were given the 2nd set of BM, Paper 2, Section A question. Their marks were recorded. Pupils were interviewed by researcher. A number of questions were asked to them. The questions were mainly to know about the usage of DBP online among pupils, how far GAPE activity motivated them to learn $\mathrm{BM}$ and pupils confidence in communication after GAPE activity carried out. Pupils' answers were recorded and transcripted.

\section{Reflect}

The mean of students' marks for BM, Paper 2, Section A before and after implementing GAPE activity were compared. This quantitative data was analysed using SPSS software. Pupils' answers for the interview questions were analyzed too. NVivo software was used to analyze this qualitative data. Conclusions were made based on findings.

\section{Result}

A pre-test was given to pupils before the GAPE activity was implemented. After that, a post test was given to them. The mean of both marks that pupils got in the tests were compared at the end of the research to answer the first research question.

Research question 1: How far pupils' Malay language vocabulary of verbs has been improved through GAPE activity?

When the mean of both marks that pupils got in the tests were compared, found that there is 1.1 increment in mean of post-test if compared with pre-test. This shows a positive result. On the other hand, researcher found that $70 \%$ of the pupils got higher marks in post-test while one person got lower marks in posttest. However, $27 \%$ of pupils' marks remain the same. 
Research question 2: How far pupils are feeling motivated to learn Malay language through GAPE activity?

Motivation to learn is one of the internal factors that influence the learning achievement (Hetika et al, 2017; Ita Afrie et al., 2017). So, pupils must first have the courage and motivation to learn to improve their vocabulary, mainly verbs. Questions were asked to the pupils to know whether GAPE activity improves their motivation to learn BM. Examples of pupils' answers are as follows, "It is very good. I feel motivated to learn BM", "I like this activity very much. I will be waiting for BM lessons" and "Learning is more enjoyable. I want to learn BM".

Pupils' answers show that GAPE activity does motivate them to involve in BM lessons. This will lead to a positive approach to teach and learn vocabulary effectively. This fact is supported by Baroroh (2019), who says pupils' active participation in learning and teaching activities can enhance their achievement.

Research question 3: How far pupils are feeling confident to communicate in Malay language after the GAPE activity?

Confidence is a fundamental part which can aid pupils to speak and communicate to share their ideas effectively (Baroroh, 2019). In conjunction with the statement, pupils were asked if GAPE activity helped them in communicating confidently. Some of pupils' answers are as follows, "Yes, by giving me the confidence to talk in BM", "Yes of course, before this I was always scared to speak in BM but now I have the courage to speak even though I'm not very good", "I feel free to use the new words when talking with my friend. I feel braver" and "Yes. I can talk with my friends confidently".

Pupils' answers clearly show that they do feel confident to talk after the implementation of GAPE activity. They said it helps them to be brave to speak, Meantime, pupils are actually still in the learning process. Their confidence to speak and learn will lead them to success in vocabulary learning. They can learn more verbs in future if this continues.

Results and findings show that there is positive improvement in pupils' vocabulary of verbs, motivation to involve in Malay lessons and confidence to communicate using Malay language. The findings also correspond with research objectives.

\section{Discussion}

This research is all about implementation of GAPE activity in Bahasa Melayu subject to improve pupils' vocabulary of verbs. Mean of pupils' marks in pre and post tests were compared. Then, an interview with the same pupils was done and analyzed. The findings show a positive result overall.

It shows that there are improvements in pupils marks in the sentence constructing section in BM Paper 2 after applying GAPE activity. This section was chosen because pupils need to identify the correct verb and make a sentence of it according to the picture which will help them to get 2 marks for each correct sentence. If pupils write a wrong verb, they will lose 2 marks even if their sentence is correct. Pupils can at least get 1 mark for each correct verb.

To find the effectiveness of GAPE activity, a BM, Paper 2, Section A question was given to the pupils before the GAPE activity. Their marks were collected. Then, after implementing the GAPE activity, another BM, Paper 2, Section A question was given to the pupils. The marks were collected again. The mean of both marks were calculated and compared.

Mean of the pre-test is 4.87 whilst the post-test mean is 5.97. The mean comparison shows that there is an improvement in the post test marks. Other than that, $70 \%$ of the pupils got higher marks in the post test. This clearly shows that GAPE activity does help in improving pupils' Malay vocabulary of verbs. 
An interview was done to the pupils to answer this research question. Pupils' answers were collected and analyzed by researcher. It shows that pupils are enjoying the BM lesson with GAPE activity. It is proven when the pupils said the lesson is interesting, good, feeling wanted to involve and more. $37 \%$ of the pupils said directly that GAPE activity motivates them to learn BM. On the other hand, $90 \%$ of pupils' answers show that this lesson is entertaining and they like it because it is enjoyable which indirectly tells that this activity does motivate the pupils to learn. This is because an enjoyable lesson will attract them to learn more (Huseyin, 2018; Emrullah, 2020).

Interview also shows that GAPE activity has boosted the pupils' confidence in communicating in Malay. Based on the analysis, 67\% of pupils said that they feel more confident and brave to at least try communicating in Malay because now they have improved in their vocabulary as well. Others said that they can understand malay sentences and are able to make more friends through speaking Malay.

The findings of this research is significant with previous studies that discussed earlier. It is clear that acquisition in the vocabulary of verbs can enhance the sentence making ability in pupils. This will lead them to make sentences with correct verbs in BM, Paper 2, Section A questions. This is supported by Hazlina et al. (2017) who hi-lighted Dulay et al. (1982) opinion in their studies which say the wrong selection of verbs will influence the meaning of a sentence.

The singing activity in GAPE is able to motivate pupils into learning Bahasa Melayu. Majority of the pupils said that BM lessons are interesting and enjoyable. This is because the GAPE activities are entertaining. As said by Ulrike (2017), the singing activity can create a positive feeling in pupils towards a positive learning atmosphere. This is also parallel with Siti Rohani et al. (2020)'s opinion that creative approach in teaching leads to active participation of the pupils in teaching and learning activity. She also said that this approach will avoid a monotonous atmosphere in class.

The analysis shows that pupils are also feeling more confident to communicate in Malay language after the implementation of GAPE activity. This fact is equivalent to Wenying and Guofang (2017)'s findings which also proves that repeating the words persistently when singing will develop the pupils' capability to use the word naturally when speaking the language. Pangkuh (2020) and Yee (2016) also emphasized similar points in their studies. They pointed that vocabulary as an important element which links in development of other language skills. As Dwi (2018), Eunice (2019) and Yuyun (2017) stated in their research, pupils will have a successful two-way communication in Malay if their vocabulary acquisition is good. This can be a reason why pupils feel braver and more confident to speak in Malay after involving in the GAPE activities.

The findings are also in accordance with the learning theory used in this research, the Revised Bloom Taxonomy which stands with remember, understand, apply, analyze, evaluate, create. In GAPE activity, pupils need to remember a word, understand the meanings, apply it in the sentences, analyze the complete sentence, evaluate whether the word chosen is according to the situation in the sentence, then create a correct sentence. The same process also must be done by the pupils when they are speaking.

This study must be conducted to improve Malay vocabulary of verbs among pupils of NTS to help them master in Malay language. The result of this study is beneficial to pupils, parents, teachers, school administrators, researchers and other interested individuals because this study provides data as bases for suggestions on improving vocabulary in Malay language.

Pupils will be able to learn in an enjoyable atmosphere. They will have the opportunity to find the meaning of words in the fastest way. The pupils will learn more new words. Besides that, they will know how to evaluate and choose the correct synonym of word. They will then be able to apply it in a song and sing. This will then result in remembering the word and use it in writing and speaking effectively.

This study will also benefit the parents. As the Tik Tok social media is trending now, many people are in an urge to use it. Neither pupils are not missed. This will be a great agonise for the parents on their children's cyber safety. In this case, GAPE can be a supersede of Tik Tok. It gives the pupils a chance to recreate and sing a song, then video record it. 
Whereas for teachers, this study will give them ideas and information about the GAPE activity implementations and the advantages of it. Teachers can carry out this activity in class to improve pupils' vocabulary of verbs in Malay which will help them to master Malay language. It will also help teachers in providing an entertaining and educational learning environment to the pupils.

Furthermore, school administrators, especially the Head of Malay Panel, can benefit from this study by choosing GAPE as one of their panel's yearly activities. As a result, the pass percentage of Malay language can be increased.

Despite this fact, the researcher hopes that the result of this study would also be a great help to future researchers and to all people who are interested in improving the vocabulary of verbs in Malay language. This is because it leads to a better acquisition of Malay language.

The implementation of GAPE in Malay teaching and learning activity gives a whole new experience to researcher. This different way of teaching took some time for the pupils to get used to. In the beginning of the research, the researcher felt perturbed but managed to build confidence as time goes on.

In the implementation process, researcher found that pupils were enjoying the lesson especially the singing. On the other hand, the researcher realised that this GAPE activity will benefit the pupils and also the teachers. Therefore, researcher decided to implement this activity in other classes too.

However, the researcher had some limitations in this study which led to few suggestions that will be beneficial for future research. Firstly, this research was focused on NTS pupils only. Future research can be done to national Schools, secondary schools and Malaysian based private schools' pupils. Secondly, researcher carried out GAPE activity for 30, year 5 pupils only. In future this research might be done to a bigger number of pupils for other standards. Thirdly, in this research, the researcher did GAPE for Malay language only. This activity can be implemented in other languages in future. Finally, a different type of suitable dictionary can be used to find meaning of words in GAPE activity. Researcher can use offline dictionary applications. This will be helpful for pupils who don't have internet access.

\section{Conclusion}

In overall, this research was carried out to improve NTS pupils' vocabulary of verbs in Malay language. The data collected shows that the GAPE activity is effective in this case. Also found that pupils feel more motivated to learn Malay language and communicate in Malay.

This activity is strongly recommended to be implemented in Malay lessons so that pupils will benefit from it. They can improve their vocabulary of verbs. This will help them to master the language strongly. Mastering Malay language will help the pupils in many ways in their future. In addition, apart from pupils, other parties such as teachers and parents are also likely to be benefited from GAPE activity as has been discussed earlier.

\section{References}

Abdul Majid Khan, A. R. (2015). Penyeliaan Klinikal dari Perspektif Pengajaran di Sekolah. PTS Professional, Malaysia.

Abdul Wahab, M. K. A. (2019). Potensi falsafah bahasa untuk Penyatupaduan nasional: Pandangan guru bahasa Melayu. Sains Insani, 4(1), 85-96. doi:10.33102/jsi2019.4.1.12

Adesoji, F. A. (2018). Bloom taxonomy of educational objectives and the modification of cognitive levels. Advances in Social Sciences Research Journal, 5(5). doi:10.14738/assrj.55.4233

Ajisoko, P. (2020). The use of Duolingo apps to improve English vocabulary learning. International Journal of Emerging Technologies in Learning, 15(7), 149-155. doi:10.3991/ijet.v15i07.13229 
Al-Baekani, A. K., Srisudarso, M., \& Pahlevi, D. M. R. (2018). Basic English (introduction to English as general communication). Yogyakarta, Indonesia: Deepublish Publisher.

Alhaisoni, E. (2016). Efl teachers' and students' perceptions of dictionary use and preferences. International Journal of Linguistics, 8(6), 31-52. doi:10.5296/ijl.v8i6.10267

Alharbi, M. A. (2016). Using different types of dictionaries for improving Efl Reading comprehension and vocabulary learning. JALT Call Journal, 12(2), 123-149.

Alisaari, J., \& Heikkola, L. M. (2017). Songs and poems in the language classroom: Teachers' beliefs and practices. Teaching and Teacher Education, 63, 231-242. doi:10.1016/j.tate.2016.12.021

Al-Musthofa. (2019). Iconelt. In International Conference On English Language Teaching (pp. 179183). Atlantis Press.

Alshahrani, H. A. (2019). Strategies to improve English vocabulary and spelling in the classroom for ell, esl, Eo and Ld students. International Journal of Modern Education Studies, 3(2), 65-81. doi:10.51383/ijonmes.2019.41

Al-Sobhi, B. M. S., \& Preece, A. S. (2018). Teaching English speaking skills to the Arab students in the Saudi school in Kuala Lumpur: Problems and solutions. International Journal of Education and Literacy Studies, 6(1), 1-11. doi:10.7575/aiac.ijels.v.6n.1p.1

Astuti, W. (2016). Berbagai strategi Pembelajaran Kosa Kat bahasa Arab. Journal Al-Manar, 5(2).

Baharudin, A. Z., Embi, M. A., \& Hashim, H. (2019). The effectiveness of using Wordaisy module to improve number of vocabulary among year three pupils. International Journal of Education, Psychology and Counseling, 4(26), 37-45.

Bahtiar, Y. (2017). Using the total physical response to improve students vocabulary mastery. Sell, 2, 1.

Baroroh, H. S. K. (2019). The correlation between Efl learners' self confidence and oral communication proficiency at Iain Tulungagung.

Bicen, H., \& Kocakoyun, S. (2018). Perceptions of students for gamification approach: Kahoot as a case study. International Journal of Emerging Technologies in Learning, 13(2), 72-93. doi:10.3991/ijet.v13i02.7467

Bischoff, S., Parker, M., \& Mishra, M. (2020). Action research in an Ethiopian classroom: Instructional methods that improve vocabulary retention. Jtar, 6(2), 83.

Bradbury, H., Lewis, R., \& Embury, D. C. (2019). The Wiley handbook of action research in education. Craig A. Mertler. : John Wiley \& Sons.

Burnard, P., \& Murphy, R. (2017). Teaching music creatively. London: Routledge.

Choo, Y. B., \& Wahab, H. A. (2016). An action research of using vocabulary wheel to improve year 2 pupils vocabulary in the Malaysian classroom. English Education, 1(2), 77-83.

Cremin, T., \& Barnes, J. (2018). Creativity and creative teaching and learning. In T. Cremin \& C. Burnett (Eds.), Learning to teach in the primary school (4th ed). Routledge.

Dalimunthe, M. (2018). The implementation of Simon Says Game to improve students vocabulary mastery in learning English at Mts. Laboratorium Uin-Su Medan. Vision, 14(14).

Dziemianko, A. (2017). Dictionary form in decoding, encoding and retention: Further insights. ReCALL, 29(3), 335-356. doi:10.1017/S0958344017000131

Ekren, G., \& Keskin, A. P. D. N. O. (2017). Using the revised bloom taxonomy in designing learning with mobile apps. Glokal, 3(1).

Erdem, E., \& Soylu, Y. (2020). Views of teachers and 7th graders on an enriched learning environment designed for improving mathematical reasoning. European Journal of Education Studies, 7(11).

Ernila, D., \& Susanti, S. (2018). Enlarging vocabulary to improve writing descriptive text of junior high school students using spider concept map. Sustainable teacher professional development in English language education: Where theory, practice, and policy meet, P. 75.

Farida, D., Isrina, H. D., \& Apsari, Y. (2019). The implementation of flash cards to improve Students'vocabulary mastery. Project (professional journal of English education), 2(3), 352-357.

Fox, C., \& Gorman, K. (2017). Confident communication for leaders. Australia: Life Performance Books.

$\mathrm{Gu}, \mathrm{C}$. (2017). On the relationships between creative learning, creative teaching, and roles of creative teachers. In. Advances in Higher Education and Professional Development. IGI Global, (494512). doi:10.4018/978-1-5225-0643-0.ch022

Halim, H. A., Hoon, A. L., \& Fan, H. K. S. (2017). Kesilapan struktur ayat bahasa Mandarin dalam kalangan pelajar penutur natif. Jurnal Kesidang, 2(1), 203-223. 
Harasim, L. (2017). Learning theory and online technologies. New York: Routledge.

Harian, S. (2018). Kpm Lancar Kempen guru Pembelajaran Abad Ke-21. Disember. Retrieved from https://www.sinarharian.com.my/Article/3275/Berita/Nasional/Kpm-Lancar-Kempen-GuruPembelajaran-Abad-Ke-21, 20.

Hasbullah, H., Mohd Yusof, S. B., Yaumi, M., \& Babikkoi, A. M. (2018). Improving vocabulary using A computer-based flashcard program. International Journal on Advanced Science, Education, and Religion, 1(1), 31-36. doi:10.33648/Ijoaser.V1i1.4

Husain, M. A. (2017). The use of Scattergories game to improve the vocabulary mastery (A quasiexperimental research in the eight grade students of Smp N 2 Demak in the academic year 2016/2017) (Doctoral Dissertation, Universitas Negeri Semarang).

Jasni, Siti R. Suhaila Zailani@Ahmad and hakim Zainal.2020. Impak pendekatan kreatif dalam pengajaran dan Pembelajaran Kosa Kata Arab. Bitara International Journal Of Civilizational Studies And Human Sciences, 3(1):010-021.

Kamarudin, R., Abd Majid, F., Mohd Zamin, A. A., \& Mat Daud, N. S. (2019). L2 learners' receptive and productive knowledge of phrasal verbs. International Journal of Education and Literacy Studies, 7(4), 144-149. doi:10.7575/aiac.ijels.v.7n.4p.144

Kingsley, T. L., \& Grabner-Hagen, M. M. (2018). Vocabulary by gamification. Reading Teacher, 71(5), 545 - 555. doi:10.1002/trtr.1645

Kunnu, W., Sukwises, A., Wangsomchok, C., Treeklangdorn, K., \& Phuboonsri, P. (2020, March). The development of Students'online dictionary skills. In International academic multidisciplinary research conference in Malta, 2020 (pp. 122-127).

Laisiyah. (2017). The correlation Betweem self-confidence and speaking achievement of the undergraduate student of English study Program of Uin Raden Patah Palembang [Thesis]. Palembang, Indonesia: English Education Department Tarbiyah and Teaching Training Faculty. UIN Raden Patah.

Lestari, N., \& Yulia, Y. (2018). The use of crossword puzzle to improve vocabulary mastery of the fifth grade students of Sd N Golo. JELLT, 2(2), 71-80. doi:10.36597/jellt.v2i2.3275

Lew, R. (2016). Can A dictionary help you write better? A user study of an active bilingual dictionary for Polish learners of English. International Journal of Lexicography, 29(3), 353-366. doi:10.1093/ij1/ecw024

Lew, R., \& Szarowska, A. (2017). Evaluating online bilingual dictionaries: The case of popular free English-Polish dictionaries. ReCALL, 29(2), 138-159. doi:10.1017/S0958344016000252

Lin, D. T. A., Pandian, A., \& Jaganathan, P. (2017). Facilitating learner autonomy: Reading and effective dictionary use for lexical development. Reading Matrix: An International Online Journal, 17(2).

Listyaningrum Arifin, W. L. (2017). Psychological problems and challenge in EFL speaking classroom. Register Journal, 10(1), 29-47. doi:10.18326/rgt.v10i1.29-47

Lusiana, I. A., Setyosari, P., \& Soetjipto, B. E. (2017). The Application of TwoStay two Stray (TSTS) and Fan-N-Pick Learning Models to Improve Students' Motivation and Learning Outcomes on social studies Subject. International Journal of Academic Research in Progressive Education and Development, 6(3), 97-108.

Ma, J. H., \& Cheon, H. J. (2018). An experimental study of dictionary use on vocabulary learning and Reading comprehension in different task conditions. International Journal of Lexicography, 31(1), 29-52. doi:10.1093/ijl/ecw037

Maden, A. (2020). Comparison of student attitudes towards printed and digital dictionary use: A case of middle school. Dil ve Dilbilimi Çalışmaları Dergisi, 16(2), 835-848. doi:10.17263/jlls.759322

Mahadi, M. (2018). Menelusuri pengajian Melayu: Siri ilmiah Apm-itbm. Malaysia: Institut Terjemahan Dan Buku Malaysia Bhd.

Mekheimer, M. A. (2018). Effects of E-dictionaries on Reading comprehension and vocabulary learning in Efl college students: A re-examination. Journal of the Faculty of Education at Beni Suef, 1, 413-464.

Muhammad, Siti R., \& Shari, S. N. (2020). Kesalahan tatabahasa bahasa Melayu dari aspek morfologi dalam Penulisan Karangan murid sekolah rendah [Grammatical error in bahasa Melayu essay writing among elementary school students]. International Social Science and Humanity Journal, 3(2), 77-89. 
Murad, D., Wang, R., Turnbull, D., \& Wang, Y. (2018, October). Slions: A karaoke application to enhance foreign language learning. In Proceedings of the 26th ACM International Conference on Multimedia (pp. 1679-1687).

Nin, E. L. Q., \& Dhamotharan, M. (2019). Vocabulary journaling to improve Reading comprehension. Advances in Social Sciences Research Journal, 6(5).

Nor, M. M., Salleh, N. M., \& Baharum, H. (2017). Kesilapan penggunaan kata kerja dalam kalangan pelajar Melayu ketika Menstruktur ayat dalam Penulisan bahasa Sepanyol. Educatum Journal of Social Sciences, 3(1), 1-9.

Noviyanti, R., Bahri, S., \& Nasir, C. (2019). The use of think bingo game to improve students' vocabulary mastery. Research in English and Education Journal, 4(1), 1-8.

O'Connor, R. E., Sanchez, V., Beach, K. D., \& Bocian, K. M. (2017). Special Education Teachers Integrating Reading With 8th Grade U.S. History. Learning Disabilities Research and Practice, 32(2), 99-111. doi:10.1111/ldrp.12131

Palpanadan, S. T., Atim, A., Kair, Z. A., Ravana, V. K., \& Mohammad, M. A. (2019). Improving Studentsâ€ $€^{\mathrm{TM}}$ mastery of vocabulary through flip book approach. English Literature and Language Review, 5(7), 117-122.

Pan, Y. C. (2017). Teaching vocabulary to improve Reading comprehension. Studies in Literature and Language, 15(4), 38-40.

Peng, C. F. (2016). Masalah Pembelajaran bahasa Melayu dalam kalangan murid cina sekolah rendah [Learning problem of Malay language among the Chinese Pupils Primary School]. Jurnal Pendidikan Bahasa Melayu, 6(2), 10-22.

Rahman, F. A. (2018). Tahap Penguasaan Kemahiran bertutur bahasa Melayu dalam kalangan murid bukan penutur Natif [The level of proficiency of Malay speaking skills among non-native students]. Jurnal Pendidikan Bahasa Melayu, 8(2), 74-83.

Rahman, N. A. A., \& Amin, N. M. (2018). PETAH as Malay language learning tools to improve communication skills. International Journal of Modern Languages and Applied Linguistics, 2(2), $62-68$.

Ratmini, R., \& Dahlia, D. (2019, July). Dampak penggunaan aplikasi online dictionary Pada Pembelajaran bahasa inggris di Ma al-Hidayah muara Telang. In Prosiding Seminar Nasional Program Pascasarjana Universitas Pgri Palembang.

Share, T. P. (TPS) as Method to Improve Student's Learning Motivation and Learning Achievement. (2017). Hetika, Farida, I., \& Sari, Yeni P. Dinamika Pendidikan, 12(2), 125-135.

Sievers, U. (2017). Creative teaching - Sustainable learning. Books on demand, Norderstedt.

Sivaratanam, S. (2019). Penguasaan golongan Kata Dalam Kalangan Murid Sjkt. Rumpun Jurnal Persuratan Melayu, 1-24.

Sudarsana, I. K. (2018). Optimalisasi penggunaan teknologi dalam Implementasi Kurikulum di sekolah (Persepektif teori Konstruktivisme). Cetta. Jurnal Ilmu Pendidikan, 1(1), 8-15.

Sulistiana, E., Nadzifah, W., \& Arifin, M. S. (2019). Intensive English Program (Iep) meningkatkan Penguasaan vocabulary. Jurnal Studi Guru Dan Pembelajaran, 2(3, September-December), 236240. doi:10.30605/jsgp.2.3.2019.46

Syahril, I. (2017). The correlation among intrapersonal intelligence, learning styles, self-confidence, and speaking ability of the second 42 semester students of English Education Study Program of Pgri University of Palembang. ELTE Journal, 5(2), 16-28.

Takkaç Tulgar, A. T. (2017). Dictionary use of undergraduate students in foreign language departments in turkey at present. Universal Journal of Educational Research, 5(12B), 51-57. doi:10.13189/ujer.2017.051406

Tobia, K. P. (2020). Testing ordinary meaning: An experimental assessment of what dictionary definitions and linguistic usage data tell legal interpreters. Harvard Law Review, 133.

Tomczak, E., \& Lew, R. (2019). 'The Song Of Words' Teaching Multi-Word Units With Songs. 31: The Southeast Asian. 3L the Southeast Asian Journal of English Language Studies, 25(4), 16-33. doi:10.17576/3L-2019-2504-02

Tridinanti, G. (2018). The correlation between speaking anxiety, SelfConfidence, and speaking achievement of undergraduate EFL students of private university in Palembang. IJELS, 6(4), 3539. doi:10.7575/aiac.ijels.v.6n.4p.35

Uswahsadieda, L., Bimantoro, R., Wildan Muzakie, A., Bagus, T. A., \& Rahmawati, R. P. (2020, May). The effect of using dictionary to develop students' vocabulary in Mts. 
Wati, M. H. (2020). The correlation between self-confidence and the students' speaking achievement (Doctoral dissertation, IAIN Kediri).

Widayanti, D. (2018). Penggunaan Model Pembelajaran "Make a Match" Dapat Meningkatkan Motivasi dan Hasil Belajar Materi Mengenal Malaikat dan Tugasnya Pada Siswa Kelas IV SD Negeri III Jaten Tahun 2015/2016. Jurnal Pendidikan Dwija Utama: Edisi Ogos. Sang Surya Media, Indonesia.

Widyaningsih, G. E. N. (2019). Penggunaan Kamus digital dan Kamus cetak terhadap Penguasaan Hanzi. Jurnal Ilmiah Edukasi \& Sosial, 10(1), 34-41.

Wilson, A. (2019). The implementation of buddy vocabulary cards technique to improve Reading comprehension.

Yunos, M. A. M. (2018). Agensi Perancangan bahasa Melayu di Malaysia: Usaha dan Cabaran Memartabatkan bahasa kebangsaan. Menelusuri pengajian Melayu. Malaysia: Institut Terjemahan Dan Buku Malaysia Bhd. Malaysia.

Zahid, I., \& Haron, R. (2019). Kata kerja dan komunikasi Berkesan dalam kitab tib muzium Terengganu edisi dan Huraian teks. Bitara International Journal of Civilizational Studies and Human Sciences, 2(4), 27-42.

Zhou, W., \& Li, G. (2017). The effects of shared singing picture book instruction on Chinese immersion kindergarteners' spoken vocabulary recall and retention. Frontiers of Education in China, 12(1), $29-51$. 